\title{
Bridging Home: Building Relationships Between Immigrant and Long-Time Resident Youth
}

\section{Citation}

Dryden-Peterson, Sarah 2010. Bridging home: Building relationships between immigrant and long-time resident youth. Teachers College Record 112, no. 9: 2320-2351.

\section{Published Version}

http://www.tcrecord.org/Content.asp?Contentld=15947

\section{Permanent link}

http://nrs.harvard.edu/urn-3:HUL.InstRepos:40898637

\section{Terms of Use}

This article was downloaded from Harvard University's DASH repository, and is made available under the terms and conditions applicable to Open Access Policy Articles, as set forth at http:// nrs.harvard.edu/urn-3:HUL.InstRepos:dash.current.terms-of-use\#OAP

\section{Share Your Story}

The Harvard community has made this article openly available.

Please share how this access benefits you. Submit a story.

Accessibility 


\title{
Bridging Home: \\ Building Relationships Between Immigrant and Long-Time Resident Youth
}

\author{
$\underline{\text { Cover Page }}$
}

Author Details

Name of author: $\quad$ Sarah Dryden-Peterson

Email address: sarah_dryden@post.harvard.edu

Biographical Statement

Sarah Dryden-Peterson is a doctoral candidate at the Harvard Graduate School of Education. She conducts research on migration in Uganda, Canada, and the United States with particular interests in local integration of refugees in countries of first asylum and the role of schools in the reception of refugees and immigrants. Her recent work has been published in the Journal of Refugee Studies, Refugee Survey Quarterly, and the International Journal of Education Development. Dryden-Peterson has taught middle school in Boston and founded a non-profit in South Africa.

One- or two-sentence description of the article (for the contents page) Using portraiture, this article examines how immigrant and long-time resident youth build relationships with each other and identifies processes of personal interaction, cooperative action, and collective identification as central to the building of these bridging relationships. 


\title{
Bridging Home: \\ Building Relationships Between Immigrant and Long-Time Resident Youth
}

\begin{abstract}
$\underline{\text { Structured Abstract }}$
Background: There is rising evidence that relationships that bridge between immigrants and long-time residents are critical to immigrant integration and to the overall heath of communities. The processes by which this bridging social capital is built are not well understood. Schools in new immigrant destinations, as spaces in which diverse youth come together, provide a unique opportunity to examine how immigrant and long-time resident youth connect to each other and build relationships.
\end{abstract}

Purpose: This article examines the processes of building relationships between immigrant and long-time resident youth and explores the meaning and consequences of these processes for the individuals involved. The article further suggests ways in which schools might adopt strategies to promote personal interaction, cooperative action, and collective identification to aid in the development of these relationships.

Setting: Lewiston, Maine is the setting of this study. Between February 2001 and May 2003, 1,200 Somalis arrived in Lewiston, a town of 35,690 people, $97.3 \%$ of whom were White at the time of the 2000 Census.

Research Design: Using the methodology of portraiture, this study examines, as an exemplary case, one relationship between two students, a Somali immigrant and a White long-time resident. Portraiture is a methodology built on relationships, which mirrors the theoretical issues under investigation.

Findings/Results: This study provides new insights into how bridging relationships are built. The participants capitalized on the common space of their new immigrant destination school to transform casual personal interactions into a bridging relationship based on collective identification. Through dialogue, particularly about race, they challenged each other and themselves, and each came to understand the other in new ways; they also became invested in each other and dependent on each other to grow and to understand themselves and their places in a changing town.

Conclusions/Recommendations: The research identifies processes of personal interaction, cooperative action, and collective identification as central to the building of bridging relationships. It also reveals the value of a focus on race 
when researching, analyzing, or cultivating these relationships. Lessons for educators and schools seeking to foster relationships between immigrant and long-time resident youth include engaging students in direct dialogue about race and cultivating skills in empathetic storytelling and listening in order to "doublethink" or receive a counter-story. 


\title{
Bridging Home: \\ Building Relationships Between Immigrant and Long-Time Resident Youth
}

\author{
Executive Summary
}

\begin{abstract}
Background and Purpose
There is rising evidence that relationships that bridge between immigrants and long-time residents are critical to immigrant integration and to the overall heath of communities. This article examines the processes of building relationships between immigrant and long-time resident youth and explores the meaning and consequences of these processes for the individuals involved.

In contrast to resegregation of schools in the United States, schools in new immigrant destinations are frequently spaces in which diverse youth come together. These schools thus provide a unique opportunity to examine how immigrant and long-time resident youth connect to each other and build relationships. Yet just as contact between diverse youth is declining in schools nationwide, so too bridging social capital is often elusive. Bridging social capital is indeed difficult to create, with race and ethnicity as the largest barriers. Yet, if bridging relationships are so critical, how do immigrant and long-time resident youth build them, and what role might schools play in this process?
\end{abstract}

\section{Research Design}

Using the methodology of portraiture, this study examines, as an exemplary case, one relationship between two students, a Somali immigrant and a White long-time resident. The students live in Lewiston, Maine; between February 2001 and May 2003, 1,200 Somalis arrived in Lewiston, a town of 35,690 people, $97.3 \%$ of whom were White at the time of the 2000 Census.

Portraiture is a methodology built on relationships, which mirrors the theoretical issues under investigation. Of critical importance to this topic of study, it privileges the perceptions and understandings of participants and actively pursues "silences" in narratives and conversations.

\section{Conceptual Framework}

A synthesis of equal status contact theory, social capital theory, social identity theory, and Critical Race Theory (CRT) provides insights into the social, psychological, and political processes involved in building relationships between immigrants and long-time residents.

Drawing on equal status contact theory helps to clarify the content of associational activities that can promote social capital-building across lines of difference. Equal status contact theory underscores the importance of personal 
interaction, which allows people to know each other as individuals. Further, equal status contact theory demonstrates that associational activity involving cooperative action, where individuals work interdependently toward common goals, is effective at creating the equal status conditions under which prejudice reduction happens.

New theoretical work that fuses social identity theory with social capital theory sheds light on the processes by which this cooperative action fosters relationships that bridge across lines of difference. The work of social identity theorists brings psychological factors to bear on the largely economically-minded field of social capital. Instead of instrumental motivations for building relationships, they posit that, in engaging in cooperative action, individuals begin to feel a sense of "we-ness" or collective identification.

Equal status contact theory also specifies the need to consider the favorability of social norms for intergroup contact. Norms about race are central factors shaping the building of relationships between immigrants and long-time residents. Critical Race Theory (CRT) provides a theoretical framework that helps to place race at the center of the analysis of the processes of personal interaction, cooperative action, and collective identification in building bridging relationships between immigrant and long-time resident youth.

\section{Findings}

The relationship between the participants in this study - named Hassan and Michelle - highlights the relevance of more than fifty years of research on interracial contact to contact between immigrant and long-time resident youth. The catalyst for their relationship was the contact they had in their school. Yet other students in their classroom did not have the same experience. While cooperative classroom experiences allowed Hassan and Michelle personal interaction through which they developed an interest in knowing each other better, they were but the jumping off point for a deeper relationship created outside of classroom structures.

First, unlike their classmates, Hassan and Michelle talked openly about their differences, most particularly about race, in ways that most Americans do not. In talking directly about race, Hassan and Michelle modeled for other youth and for educators a difficult endeavor. The outcome is illuminating in its effects on their bridging relationship: Through talk about race, Hassan and Michelle helped each other to understand the world from each other's point of view, creating within their relationship recognition of their individual differences and strengths.

Second, Hassan and Michelle practiced a skill Hassan labeled "doublethink,” putting yourself in someone else's shoes. Hassan and Michelle demonstrated the potential impact of explicitly using this strategy as a way to 
foster understanding between students. Hassan and Michelle used skills of both storytelling and listening to "double-think" enabling mutual understanding of each other as individuals as well as of the experiences of the spaces they each inhabited, particularly their school and the Lewiston community. They began to see themselves as a collective and to feel a sense of "we-ness."

This transformation of identity may be the most critical, and yet to date the least theorized, process in building bridging relationships. Hassan and Michelle demonstrated that mutual investment was central to the transformation of identity, as social identity theorists have long argued. They took the time to explain their thinking and to expose their tensions because they cared that the other person understood. They learned from each other about the role of race in the institutions - school, family, municipality - that they inhabited. Hassan and Michelle's examples suggest that experiences in personal relationships created through institutions such as schools might lead, over time, to collective identification.

\section{Conclusion}

Hassan and Michelle capitalized on the common space of their new immigrant destination school to transform casual personal interactions into a bridging relationship based on collective identification. Through dialogue, particularly about race, they challenged each other and themselves, and each came to understand the other in new ways; they also became invested in each other and dependent on each other to grow and to understand themselves and their places in a changing town. This portrait contributes to theoretical understandings of the processes of personal interaction, cooperative action, and collective identification that contribute to the building of bridging relationships between immigrant and long-time resident youth. It also reveals the value of a focus on race when thinking about, researching, or cultivating these bridging relationships. It is hoped that Hassan and Michelle's examples might inspire youth and adults in schools across the country to use strategies such as direct dialogue about race and "double-thinking” to foster bridging relationships among other immigrants and long-time residents. 


\section{Bridging Home: \\ Building Relationships Between Immigrant and Long-Time Resident Youth}

Lewiston, in a winter that comes as early as October, is a cold and dark

place. ${ }^{1}$ Dropped in the middle of Maine, it seems as huddled away from a larger world as a town could get. People walk up the street with hats pulled down over their eyebrows and scarves pulled up above their noses. As school lets out for the day, traffic along the main street slows to the mandated — and obeyed — fifteen miles an hour. Sitting in the local donut shop, I hear on one side of me the ancient French of the Québecois, still spoken by the descendants of mill workers and canal diggers who came to this area over a hundred and fifty years ago. On the other side, I hear the slow and lilting English of the Irish of central Maine. Like the folks on both sides of me who gather for afternoon coffee and donuts, the population of Lewiston is, like me, mostly White; they are also mostly Catholic, mostly old, and mostly out of work.

But not Hassan Ahmed. ${ }^{2}$ Hassan — dressed in a red pin-striped shirt, khakis, and the requisite donut shop visor — stands behind the counter confidently pouring coffee, serving donuts, and taking orders for his favorite meal: chicken stew in a bread bowl. This seventeen year-old has a dimpled and wide-eyed smile, and he radiates a kind of magnetic energy. He draws people to him. His too-big body and goofy ways make people laugh. He calls himself the class clown. But he also has the ability to "double-think,” as he calls it: to be both 
funny and genuine, both kid-like and wise, to put himself in other people's shoes. Such is not easy for a Muslim and Somali teenager in Lewiston, Maine.

Hassan's experience as an immigrant to Smalltown, USA is becoming less and less unique. The majority of immigrants to the United States continue to settle in long-established 'gateway' cities: New York, Chicago, Miami, Houston, and Los Angeles (Singer, 2004). However, during the 1990s, immigrant destinations began to change dramatically. Significant numbers of immigrants began to settle in 'non-traditional' cities and states - "new immigrant destinations” (Gozdziak \& Martin, 2005; Singer, 2004) - and, by 2000, nearly one third of immigrants to the U.S. resided outside established settlement centers (Singer, 2004). States such as Arkansas, Colorado, Georgia, Nebraska, Nevada, Tennessee, and Utah, experienced 150 percent growth in their foreign-born populations between 1990 and 2000; North Carolina led with a 274 percent increase (Migration Policy Institute, 2004).

If Hassan's family had settled in a traditional gateway city, his experiences in school would likely have been very different than they are in Lewiston, Maine. In 2004, nationwide, 73 percent of Black students and 77 percent of Latino students attended predominantly minority schools; further, 38 percent of Black and 39 percent of Latino students attended schools in which only 10 percent of students were White (Orfield \& Lee, 2006, pp. 10-11). White students were the most racially isolated, going to schools where, on average, only 20 percent of 
students were from different racial groups (Orfield \& Lee, 2006, p. 9). In contrast to this segregation in most U.S. schools, patterns of immigration to new immigrant destinations are creating opportunities for contact between immigrant youth, many of whom are people of color, and long-time resident youth, many of whom are White. For example, the kinds of small cities or towns in which immigrants are now frequently settling, like Lewiston, often have only one high school, and youth of different racial and ethnic backgrounds necessarily come together there (Bump, Lowell, \& Pettersen, 2005).

Schools in new immigrant destinations, as spaces in which diverse youth come together, provide a unique opportunity to examine how immigrant and longtime resident youth connect to each other and build relationships. This topic is understudied despite rising evidence that relationships that bridge between immigrants and long-time residents are critical to immigrant integration and to the overall heath of communities (Gozdziak, 2005; Kunz, 2003; Migration Policy Institute, 2004; Putnam, 2007). Through an in-depth portrait of one relationship between an immigrant and a long-time resident, this study examines the processes of building connections and forging a relationship and explores the meaning and consequences of these processes for the individuals involved. In the final section, lessons from this study of a relationship between individuals are applied to schools as institutions; this section includes strategies that schools might adopt to 
foster relationships between immigrant and long-time resident youth on a larger scale.

\section{Conceptual Framework: From Contact to Identification}

How do immigrant and long-time resident youth build relationships with each other? A synthesis of equal status contact theory, social capital theory, social identity theory, and Critical Race Theory (CRT) provides insights into the social, psychological, and political processes involved.

The contact hypothesis, originally proposed by Gordon Allport, states that the more contact an individual has with people who are different, or not members of his or her group, the less likely he or she is to have prejudice against members of that “outgroup” (Allport, 1979 [1954]). The literature on this theory is extensive and reviewing it is beyond the scope of this article. Pertinent to this study is that empirical work, while supporting the theory, has also established conditions under which contact is most effective at reducing prejudice (Ellison \& Powers, 1994; Forbes, 1997; Pettigrew \& Tropp, 2006; Sigelman \& Welch, 1993; Stein, Post, \& Rinden, 2000). The revised theory of equal status contact specifies four necessary conditions: first, equal status, whereby contact occurs in situations where the two groups are in an equal status; second, personal interaction, specifically one-on-one interactions among individual members of the two groups; third, cooperative activities in which members of the two groups join 
together to achieve common goals; and fourth, social norms that favor intergroup contact (Brehm \& Kassin, 1996; Brewer \& Miller, 1988; Brown, 1995).

Contact among youth in schools can theoretically satisfy all of these conditions. Yet studies of racial integration in the United States have documented that only exceptional schools are able to satisfy all of the conditions to create situations in which contact works to improve interracial attitudes and networks among Black and White students (Johnson \& Johnson, 1995; Schofield, 1995; Slavin, 1995). Indeed, overwhelming evidence points to the truth of the proverb 'birds of a feather flock together' in most relationships in the United States (McPherson, Smith-Lovin, \& Cook, 2001), including friendships among youth in diverse settings (e.g., Tatum, 2003; Weisinger \& Salipante, 2005). Equal status contact theory thus underscores the empirical distinction between simple contact, which can happen through school desegregation, and contact according to the equal status conditions outlined above, which schools must seek to create purposefully.

As previously explained, in many places in the United States, settings of desegregation are disappearing rapidly and thus possibilities for contact, let alone equal status contact, are diminished. New immigrant destinations, on the other hand, as outlined above, provide unique opportunities for contact. We nevertheless know little about the effects of contact, equal status or otherwise, on relationships between immigrant and long-time resident youth, especially in new 
immigrant destinations. While we might expect these effects to be similar to the well-studied effects on Blacks and Whites, research has shown that the effects of contact may be different for different racial groups (Tropp \& Pettigrew, 2005); further, the potential impact of such factors as language and culture make studies specific to contact between immigrants and long-time residents necessary. Among adult immigrants and long-time residents, the benefits of contact are beginning to be documented. A recent study found that, in Germany, the more inter-ethnic contact native Germans have, the less they oppose social integration of foreigners and guest workers (Coenders \& Scheepers, 2008). In the United States, a study of attitudes towards immigration policy concluded that, nationally, Anglos who have more contact with Hispanics and Asians have more liberal positions on immigration policy (Hood III \& Morris, 1997). However, the effects of contact between immigrants and long-time residents on prejudice reduction have been little explored among youth.

For immigrant integration and the health of diverse communities, social capital theory suggests that prejudice reduction achieved through contact is but the first stage in building bridging relationships (e.g., Briggs, 2003; Putnam, 2007). Bridging relationships are one form of social capital, ties built across diverse communities, which often span social cleavages such as race, country of origin, language, and religion (Gittell \& Vidal, 1998; Putnam, 2000). These relationships extend beyond the simple contact of attending the same school or 
frequenting the same grocery store. They involve a depth of relationship that would, at minimum, link an individual to external assets such as a ride (transportation) or to information such as job availability. Bridging relationships can also be more involved and include friendship or political alliance. In this way, bridging relationships are valuable because they help individuals to extend their personal and professional opportunities (Putnam, 2000; Saegart, Thompson, \& Warren, 2001). Most relevant to this study is that bridging relationships enable the recognition of mutuality, or mutual respect, among individuals (Briggs, 2003, p. $6)$.

Just as contact between diverse youth is declining in schools, so too bridging social capital is often elusive. Bridging social capital is indeed the “toughest to create” (Putnam, 2000, p. 363), with race and ethnicity as the “biggest divide in social networks today in the United States” (McPherson, et al., 2001, p. 420). Yet, if bridging relationships are so critical, how do immigrant and long-time resident youth build them, and what role might schools play in this process?

Social capital theory forwards that individuals must engage in associational activity in order to build relationships (Bourdieu, 1986; Coleman, 1988; Putnam, 2000). While social capital theory is well-developed and empirical work that measures the extent and outcomes of it is abundant, understanding of the processes of building bridging social capital are in their infancy. Drawing on 
equal status contact theory helps to clarify the content of associational activities that can promote relationship-building across lines of difference. Equal status contact theory underscores the importance of personal interaction, which allows people to know each other as individuals (Brewer \& Miller, 1984; Molina \& Wittig, 2006). While much social capital research focuses on its properties as a community- or ecological-level phenomenon (cf. Halpern, 2005; Kawachi \& Berkman, 2000; Putnam, 2000), equal status contact theory suggests the need to emphasize one-on-one interactions in the building of bridging relationships. Further, equal status contact theory demonstrates that associational activity involving cooperative action, where individuals work interdependently toward common goals, is effective at creating the equal status conditions under which prejudice reduction happens (Fishbein, 1996). Social capital theory assumes associational activity to involve cooperative action (e.g., Putnam, 2000), but it does not explain the processes by which this cooperative action fosters relationships that bridge across lines of difference.

New theoretical work that fuses social identity theory with social capital theory (Kramer, 2006) may shed light on these processes. Putnam’s definition of bridging social capital includes the notion that it "can generate broader identities" (2000, p. 23), through which we "transcend our social and political and professional identities to connect with people unlike ourselves” (2000, p. 411). However, previous empirical attempts to respond to the question of how to build 
bridging social capital have not focused on the role of identity (Kramer, 2006). The work of social identity theorists Turner and his colleagues bring psychological factors to bear on the largely economically-minded field of social capital. Instead of instrumental motivations for building relationships, they posit that, ... the general process underlying mutually co-operative intentions and expectations is the extent to which players come to see themselves as a collective or joint unit, to feel a sense of 'we-ness', of being together in the same situation facing the same problems. In other words, it appears that the fundamental process is one of becoming a psychological group (Turner, Hogg, Oakes, Reicher, \& Wetherell, 1987, p. 34).

Kramer marshals empirical evidence from the field of social identity research to support this theory, demonstrating that collective identification promotes investment in personal relationships and collective behavior in a variety of settings, including small experimental groups and large organizations and social groups (2006, p. 31). Alder and Kwon argue that this kind of reciprocity allows for a renegotiation of identity: “It transforms individuals from self-seeking and egocentric agents with little sense of obligation to others into members of a community with shared interests, a common identity, and a commitment to the common good” (2002, p. 25) 
Can immigrant and long-time resident youth overcome the propensity to flock together in order to build relationships with each other through personal interaction, cooperative action, and the development of collective identification? The fourth tenet of equal status contact theory specifies the need to consider the favorability of social norms for intergroup contact. The findings from this study, presented below, suggest that norms about race are central factors shaping the building of relationships between immigrants and long-time residents. While the theories outlined above are inherently concerned with race, they do not address how the divisive forces of racism might play a role in shaping the nature of contact, the development of social capital, or the formation of social identity. Critical Race Theory (CRT) provides a theoretical framework that helps to place race at the center of the analysis of the processes of personal interaction, cooperative action, and collective identification in building bridging relationships between immigrant and long-time resident youth.

CRT grew out of critical legal studies and sought to position race, as opposed to class, as the primary lens through which to analyze legislation and legal institutions. The development and use of CRT in education arose, similarly, in response to “critical theory’s racial blind spots” (Lynn \& Parker, 2006, p. 267). Beginning in the mid-1990s, CRT has been used in education primarily to understand school inequality (e.g., Ladson-Billings \& Tate IV, 1995; Tate IV, 1997), to critique pedagogy and practice (e.g., Foster, 1998; Iseke-Barnes, 2000; 
Ladson-Billings, 1999), and to counter stereotypes of students and parents of color (e.g., Delgado Bernal, 2002; Solorzano, 1997).

In this study, CRT is particularly useful as an overall analytic lens through which to view the way that bridging relationships are built between immigrant and long-time resident youth. It also serves several specific functions. First, it provokes scepticism about schools as spaces of "neutrality, objectivity, colorblindness, and meritocracy” (Matsuda, Lawrence, Delgado, \& Crenshaw, 1993, p. 6). As such, it promotes a critical perspective on the possibilities for equal status contact in schools.

Second, this study draws on counter-storytelling, developed out of CRT, which tells and analyzes the stories of people on the margins of society whose experiences are not often included. While this is a methodological approach, explained in more detail below, it also serves a specific analytic function. This approach is "a tool for exposing, analyzing, and challenging the majoritarian stories of racial privilege” (Solorzano \& Yosso, 2002, p. 32), which is critical to analysis of personal interactions, cooperative action, and collective identification that are embedded in racialized institutions and discourses. In seeking to understand the experiences of an immigrant and a long-time resident in relationship, this study is not limited to the counter-story but includes dominant perspectives as well in order to juxtapose the dominant discourse with the counter-story (Duncan, 2002). 
Third, as a form of scholarship, but also a form of activism, CRT is concerned with not only understanding but also fuelling change to unjust institutions (e.g., Dixson \& Rousseau, 2005; Matsuda, et al., 1993). Through a CRT framework, this study seeks to illuminate the processes of building relationships between immigrant and long-time resident youth in a way that transforms how researchers and educators construct race in understanding the experiences of immigrant youth in schools.

To do so, in this study, I analyze the experiences of one immigrant and one long-time resident who have contact and personal interaction, engage in cooperative action through their school, and come to a collective understanding of and investment in each other. This example of youth managing their new challenges of diversity mostly on their own, in unstructured and spontaneous ways, but within institutions and societal discourses, suggests lessons for schools about approaches to promoting these types of relationships in systematic ways.

\section{Site: Lewiston, Maine}

Hassan Ahmed and his family fled Somalia in 1994, just months after images of American soldiers being dragged through the streets of Mogadishu had painted a vivid and evil picture of Somalis and of Africa for the American public. Seven at the time, Hassan remembers "mostly people dying because of warlords.” Like 50,000 other Somalis, Hassan’s family was resettled as refugees in the 
United States. They lived first in Binghamton, New York, but they soon moved to Boston, Massachusetts, a place Hassan does not "think...could have gotten any ghetto-er.” Somali community representatives echoed Hassan’s feelings, writing in an open letter to the former Maine Governor King in May 2002 that "[g]iven the possessive nature of Somali parents toward their families and children, cities are seen as places where the potential for running into undesirable situations is high. These include drugs, guns and related violence.” In looking for “a safe environment in which to raise a family,” 1,200 Somalis — including Hassan’s family — undertook a further migration and settled in Lewiston.

Between February 2001 and May 2003, these 1,200 Somalis arrived in Lewiston, a town of 35,690 people, $97.3 \%$ of whom were White at the time of the 2000 Census. "Here was completely White, except for a few Somalis who were up here at that point,” says a community leader, speaking of his perception upon arrival. “And everybody on both sides was in shock. The people didn't know what this was all about. Where have all these colored women come from? And the Somalis were like, what did we get ourselves into? We came to a completely White state [and] a White city. An old mill town in the middle of nowhere. It was a far-away land.” Although this small town in Maine is half a world away from Somalia, it initially "felt more like home" to many Somalis who had previously lived in large American cities. The land seemed "big," just like Somalia. And 
people greeted each other on the street, just like in Somalia. And yet, this small, safe town turned out not to be as hospitable as many Somalis first hoped.

A year and a half after Somalis first began to arrive, the Lewiston Mayor wrote an open letter to the Somali community. He urged local Somali residents to communicate with Somalis in other states to discourage them from relocating to Lewiston.

October 1, 2002

... This large number of new arrivals cannot continue without negative results for all. The Somali community must exercise some discipline and reduce the stress on our limited finances and generosity. I am well aware of the legal rights of a US resident to move anywhere he/she pleases, but it is time for the Somali community to exercise this discipline in view of the effort that has been made on its behalf. We will continue to accommodate the present residents as best we can, but we need self-discipline and cooperation from everyone. Only with your help will we be successful in the future-please pass the word: We have been overwhelmed and have responded valiantly. Now we need breathing room. Our city is maxed-out financially, physically and emotionally.

Laurier T. Raymond, Jr. Mayor, City of Lewiston (Raymond, 2002)

This letter generated extensive national and international interest in what was happening in a small corner of Maine. A national hate group, The World Church of the Creator, saw the opportunity to turn the events in Lewiston into a major victory for White supremacy and scheduled a public meeting in the city. 
In response, over 4,500 people from Lewiston and neighboring communities came together under what was called the Many and One Coalition to reject the hate group’s position and celebrate the new diversity of Lewiston. It was the largest public gathering of support in the state's history. This rally of January 2003 marked a major shift in public perception of Somali refugees in Lewiston. City Administrator Phil Nadeau describes the complaints about Somalis that reached his desk before the rally: "I have a stack of communications, letters, emails. Without exaggeration, it's about this high,” he says, making a sharp motion with his hand to about one and a half feet off his desk. But after the rally, "[t]he telephone calls, the e-mails, the letters, and all of that literally stopped.... It isn’t because there aren’t people out there that aren’t happy, or disagree with what's going on. But there comes a point where a community begins to understand that this is the way it's pretty much going to be.” Nadeau's tone leaves the question open as to whether this is acceptance of the Somalis or desire to disassociate from White supremacy.

Five years later, there were about 3,000 Somalis in Lewiston (PerhamWhittier, 2007). They had not stopped coming but the number of arrivals had been declining. While the White Lewiston community may be understanding that “this is the way it's pretty much going to be,” the barriers between Somali and White are as high as ever. These barriers are social, spatial, and psychological. 


\section{Methodology}

Teachers at Lewiston High School identified Hassan Ahmed as someone who, unlike so many of the Somali and White students at his school, is able to make friends of different races, genders, and religions. He smiles, bemused and slightly embarrassed, when I tell him that his teachers think this of him. "You have a gift,” I say warmly. "Maybe it’s a gift, but I think it’s just the way I am,” he shrugs as if not able to imagine being any other way.

I asked Hassan to choose a close friend to be part of my study with him. Sixteen year-old Michelle Renaud is White and a long-time resident classmate of Hassan's who seemed genuinely pleased to have been chosen by Hassan as a close friend. “I was desperate,” he says jokingly, with a wave of his head and roll of his eyes; they then share warm eye contact and smiles that radiate bonds of friendship. Over the course of a school semester, Hassan, Michelle, and I engaged in twenty hours of interviews. A series of eight two-hour interviews with Hassan and Michelle were at first held separately; a final set of two two-hour interviews brought the three of us together. I audiotaped all interviews. I also shadowed Hassan and Michelle at school, navigating the confusing hallways and new block scheduling with them as my guide. Hassan and Michelle took two classes together, and I observed them interacting as they wrote essays, watched videos, and participated in class discussions. I took detailed fieldnotes in all settings. My interviews and participant observation with Hassan and Michelle were enriched 
by background interviews held over a period of two years with four teachers, two school board officials, three city officials, and five Somali community leaders as well as by hundreds of newspaper and magazine articles that have been published since 2002, with sources ranging from the Lewiston Sun Journal to the New York Times to the American Conservative.

In my search to understand the relationship Hassan and Michelle had built, I chose an approach to research that, too, is built on relationships: portraiture. Portraiture is a qualitative social science methodology that "hopes to bridge aesthetics and empiricism and appeal to intellect and emotion, and that seeks to inform and inspire and join the endeavors of documentation, interpretation, and intervention” (Lawrence-Lightfoot, 2005, p. 7). Central to the methodology is intense engagement of the portraitist (the researcher) and the participants in dialogue and co-construction of knowledge (Lawrence-Lightfoot \& Davis, 1997, p. 103).

Like all methodologies, portraiture has come under its share of criticism (English, 2000), and it was subject to recent scrutiny in the debates over "scientific" research in education (National Research Council, 2002, pp. 75-77). There has nevertheless been an increase in the use of portraiture in educational research since the publication of the National Research Council's 2002 report, Scientific Research in Education (Backenroth, 2004; Harding, 2005; Marinell, 2008; Murakami-Ramalho, Piert, \& Militello, 2008; Newton, 2005; Wright, 
2007). These empirical articles join several recent methodological contributions that argue for the particular salience of portraiture in educational research that seeks to respond directly to problems of practice (Chapman, 2007; Hackmann, 2002; Lawrence-Lightfoot, 2005).

\section{Rationale for Portraiture}

There are several reasons why portraiture is the methodology most appropriate for this study. First, the use of portraiture seeks to mirror the theoretical issues under investigation. As Fullan and Miles note in an article about school reform, the difference between successful and ineffective schools lies not in the quantity or type of their problems but in their ability to solve them (1992). Similarly, as this study will illuminate, the characteristics of effective bridging relationships are not based in innate perfect understandings between diverse people but in individuals' abilities to make space to know each other, to confront misunderstandings, and to discuss how they participate in institutions and discourses that are embedded in racism. The insistence of portraiture on engaging the researcher and the participants in dialogue - through the research process, through analysis, and through writing (Lawrence-Lightfoot \& Davis, 1997) renders the processes of building these relationships, which are so dependent on dialogue, visible to the researcher. 
Second, and related, this investigation centers on individuals' experiences with divisive forces of race, religion, country of origin, and gender. Portraiture compliments Critical Race Theory in its privileging of the perceptions and understandings of participants: "Portraitists seek to record and interpret the perspectives and experiences of the people they are studying, documenting their voices and visions — their authority, knowledge, and wisdom” (LawrenceLightfoot \& Davis, 1997, p. xv). In order to understand, analyze, and convey these perspectives and experiences, the portraitist adopts a more active research stance than is common in other qualitative methods, including narrative inquiry with which it is often compared (e.g., Chapman, 2005; Hackmann, 2002). Lawrence-Lightfoot draws on a novelist’s approach to explain one difference, quoting Eudora Welty: “Long before I before I wrote stories, I listened for stories. Listening for them is something more than acute listening to them. I suppose it's an early form of participation in what goes on” (Welty, 2003 [1983], p. 14, emphasis in original). Listening for a story means entering the participants’ perspective to understand descriptions of events and interpretations from the inside. The portraitist's empathy and openness are critical to connect with participants in this way. Further, this relationship between the portraitist and the participant allows the portraitist to "pursue the silences” (Lawrence-Lightfoot, 2005, p. 12) in conversations and in narratives. Given the immense silences 
around issues of race in this country (e.g., Pollock, 2004), this ability and responsibility of the portraitist is critical to a study of this nature.

Finally, this study is particularly concerned with the construction of relationships between youth of diverse backgrounds. Critical Race theorists are clear that "critical analysis of racism in education could lead to the development of new ways to think about the failure of schools to properly educate minority populations” (Lynn \& Parker, 2006, pp. 266-267, emphasis added). Synthesizing this perspective with the methodological approach of portraiture allows a critical analysis of racism that instead focuses on why and how some people or institutions might be successful (cf. Chapman, 2007). Lawrence-Lightfoot and Davis describe portraiture as part of a shift away from research paradigms based on pathology to ones concerned with “goodness” (1997). They write, “The researcher who asks first 'what is good here?' is likely to absorb a very different reality than the one who is on a mission to discover the sources of failure” (1997, p. 9). This search for 'goodness' — through a portraitist's stance of “acceptance and discernment, generosity and challenge” (1997, p. 141) — does not have as an end-goal an idealized portrayal or a denial of weakness and negative experience. I do not intend to shelter the reader, for example, from the realities of racism that shaped Hassan’s life in Lewiston, Maine. However, the reader who is also privileged to 'what is good here' absorbs different meaning and may be better able to apply that meaning to his/herself and to other contexts than one who is 
overwhelmed by negativity and pathology (cf. Stanton-Salazar, 1997; Valencia, 1997; Valenzuela, 2002).

With the goal of "embracing the intersection of aesthetics and empiricism" (Lawrence-Lightfoot \& Davis, 1997, p. 6), the portraitist's attention to the aesthetics of writing permit conveyance of the complexities and subtleties of empirical data. The portraitist intentionally seeks to avoid what John Dewey, quoting Bousanquet, described as “easy beauty” (Dewey, 1958 [1934]), or the "veneer of prettiness that hides the shortcuts, the laziness, and the superficiality" (Lawrence-Lightfoot, 2005, p. 9). Indeed, Lawrence-Lightfoot outlines the specific capacity of portraiture to capture, and embrace, contradictions as the portraitist seeks "to capture the raw hurt and the pleasure of her or his protagonists and works to embroider paradoxical themes into the inquiry and narrative” (2005, emphasis in original). As Bourdieu argues, it is in the depth of a single case - in this study a relationship between two people - that this complexity of human experience can be captured. He writes:

... my deepest scientific enterprise is indeed based on the belief that the deepest logic of the social world can be grasped only if one plunges into the particularity of an empirical reality historically located and dated, but with the objective of constructing it as a 'special case of what is possible,' ... that is an exemplary case in a finite world of possible configurations (Bourdieu, 1998, p. 2) 
In portraying the relationship between Hassan and Michelle as a 'special case of what is possible,' this portrait attempts to provide both "grist for the social theory mill” (Geertz, 1973, p. 23) and examples for youth and individuals who work with them as they tackle the building of relationships between immigrants and longtime residents, an issue that is so pressing for education and society in the United States.

Consistent with the aesthetic and empirical considerations of portraiture, the portrait that follows is written in a style that may be unfamiliar or even uncomfortable to some readers. In particular, in reflecting the methods of research, I, the researcher, am present with my participants in the portrait (Lawrence-Lightfoot \& Davis, 1997). Further, through thick description of complex realities and ideas, but with a guiding interpretive voice, this portrait presents data and embedded analysis. The portrait is organized conceptually around the themes that emerged from the data, and I use headings to signal the analytic categories - school as common space, forming a bridge, and coming to the collective - that emerge from these themes and that draw on the conceptual framework outlined above. I do not include citations or theoretical arguments in the portrait itself; however, I return to a theoretical analysis and contextualization of my findings in the discussion section. 


\section{School as Common Space: Contact \& Personal Interaction}

I was not prepared for the surreal scene that confronted me at Lewiston High School. From the outside, the school seems predictable enough. Students crowd the front entrance, talking and laughing away their last minutes before the bell rings. Every student I see is White; the boys are baggy-pant-clad and skateboard-toting, the girls have flared jeans, puffy coats, and sneakers. Making my way through the swirl of 1,250 students, I am actively searching for people who look different. Amid this sea of White faces are small groups of Somali students. They seem to stick together. All of the Somali girls wear headscarves, some in muted colors and others in daring fuchsia and orange; their skirts are long. One girl's dark blue jeans peak out from beneath her long, flowing skirt. Her black, clunky sandals with square heels balance the jeans and contrast with the modesty of skirt and hijab.

As I walk down the hall, I see some classes in which all of the students are Somali. In one English Language Learner (ELL) class, teacher Laurie Thompson speaks quickly, as she would to mother-tongue English speakers. All of the students in this class speak English well, but writing seems a new skill. When I arrive in class, a girl and a boy are practicing their cursive writing. On the board, they have drawn the writing guides that I remember from kindergarten, with thick lines demarcating the boundaries of letters and a dotted line in the middle to 
balance the cursive script. The girl writes 'uppity' twice, with the chalk set squarely and determinedly against the board. Laurie helps her, guiding her making of the curly letters with soft and clear instructions; "go up a little further," she says, "that line is where the letter should stop.” This same girl speaks eloquently in English to her Somali classmates before class and then puts on make-up from a compact she pulls out of her small, tuck-under-the-arm purse. She is grown-up, probably in her early 20s; but only now does she have the opportunity to learn to write.

The way that Hassan speaks, the way he writes, he could have been born speaking English. Unlike the students in Laurie's class, who are in special ELL classes with exclusively Somali students, Hassan describes himself as being in “mainstream” classes. Michelle is quick to point out that there are not very many Somalis in these classes. When there is more than one Somali student, which is rarely, the Somalis usually sit together. In English class, Hassan sits next to Michelle on one side and Jamelia, who is Somali, on the other. The class is watching Ferris Bueller's Day Off and preparing to write essays on the movie. Several students choose to use Mac G4 Powerbooks to take notes and get them out of a cupboard filled with more than enough for the class of nineteen students. There is a wireless network in the classroom, indeed in most of the school, and while the movie is going on some students check their yahoo email accounts. 
A girl walks into class, four minutes late, and says loudly: “Hey, what’s up?” The teacher laughs, not bothered by the interruption. The class feels warm, with a kind of familial tone in the relationships between teacher and students. As teacher Anita Curran passes back papers, she checks in with each student: “Are you OK?” she asks, with genuine concern. “I can totally relate,” she commiserates with a student who cannot find her notebook after cleaning the house. There is a bulletin board of photos of students engaged in myriad activities covering one complete wall, which makes the room feel populated by friends. The teacher seems to be enjoying herself with the students. While watching the video, she makes the kind of comments — "This is pretty good! Watch this...” — and laughs the way she might in her own living room.

Many of the Somali youth who now live in Lewiston, Maine and who are now using G4 Powerbooks and watching videos like Ferris Bueller's Day Off in English class lived in refugee camps just a few short years ago. Hassan does not remember being in a refugee camp; he does not remember the hundreds of children who likely populated his $1^{\text {st }}$ grade class. A laptop for each student now seems normal to him. In his distance education American Sign Language class, he playfully punches his Ed Tech on the arm and congratulates her on the new words she has learned in sign langauge. In the Kenyan refugee camp that Hassan does not remember, the notion of laughing with a teacher is foreign, and disrespectful. 
In that setting, Hassan would never have dreamed of having a friend who was White, Catholic, and a girl.

\section{Forming a Bridge: Cooperative Action}

When Somalis first started coming to Lewiston, Michelle recalls, she was in middle school. "When I first met them, I couldn’t tell them apart. Like who are you? Why won't you say 'hi' to me? But it is like now I can tell them apart and it is like you know certain things about each of them...their personality and their attitude.” At first, Hassan was “[j]ust another one of the Hassans.” But then, as Michelle begins to recall, she just went up to him and started talking. They started sitting together in math class. They are both confused when I propose that it might have been hard for them, as it is for so many other students at Lewiston High School, to get to know each other. Both describe themselves as being out-going, as the kind of people who just like to talk. Being together in school and in class made the beginnings of their friendship feel easy.

Now they hang out all the time, both with each other and in small groups of Somali and White friends. "[Michelle] is really cool, that's what I think.... You can just talk to her. You can just sit there and just talk about nothing.... She is not like other students. She don't care about her reputation. Yeah, that's it. She don't care....Other people pick friends on how cool they are.” With the maturity that Hassan recognizes in her, Michelle affectionately admits, “[Hassan] is such a 
geek... [she laughs]... But he is awesome to be around.” She smiles shyly. He is “outgoing, hands-on...he is just all around funny. Pretty cute.... He’s more shy, though, he’s just to himself. You need to open him up a bit... [she pretends to poke him]... You just joke around.” Perceptive Michelle sees both the out-going side that Hassan shows to the rest of the world and his shy side, that is there but hidden.

“I spend a lot of time with Whites,” Hassan tells me earnestly. His shell breaks then, and he tumbles into a story. "You know, sometimes I stay for hours and hours. I go over to their houses and I don’t think I am going to be there eating, and then I stay for dinner.” He smiles. Hassan’s smile is warm, his dimples dancing frequently around his face. He is of medium height; back in Somalia, people would compliment him on his healthy weight. His hair is cut close to his head. Each day, he has a variation on the baggy jeans, t-shirt, and white sneakers 'uniform' of Lewiston High. He often slouches at his desk in class when he is in passive mode. He sits back in his chair, feet out in front of him, legs spread, feet flat. He can look small. When he works, his mouth is open, his chin perched on his large hands in ultimate concentration. And when he is engaged with people, he takes up space. Talking, laughing, discussing, his hands flail in all directions, his laugh fills the room; he holds himself as one comfortable with his being and his place in the world. 
Hassan is not always comfortable, though. In comparing Lewiston to Boston, he reflects, “I feel less comfortable here just 'cause, we're the minority, you know what I mean. And, over there, I just blend in, people won't notice I'm even there 'cause there's so many. It's like taking a White person here and putting them in Boston, they'd feel the same way I feel.” I ask, "What does it feel like inside to be the minority?” He is quick to reply. “Looked at, treated like I don’t know much. They think I just arrived, or something. You know what I mean? Like I don’t know anything. Like they can take advantage of me.... Like the way they act toward us, like I don't know what they're saying and stuff.... But I have really cool friends, and they're White too.” Hassan always tempers the bad with the good. He also takes responsibility for putting himself out there, for finding the 'cool friends,' for making sure that Whites know him as a person, know that he speaks English, that he works for a living, that he pays taxes. He sees his work with the Civil Rights Team, a student group founded in 1996 at Lewiston Middle School to "celebrate diversity" and expanded to the High School after the White supremacy rally, as essential to this task. "We turn everything that's negative, positive,” he states with pride.

"I just got this gift from [the Principal] saying thank you with a card. 'Thank you for joining the Civil Rights Team. You are making a difference,’” Hassan adopts the intonation and accent of a middle-aged White man very effectively. Hassan describes how important this recognition of the Civil Rights 
Team is and about how he will keep the card in a special place. Michelle, petite and cute, dressed in a fitted purple sweater and flare jeans, sits quietly listening. Her quietness does not belie the sharp mind that I can see in her darting and wise eyes. While wisdom is not usually a word that can be applied to someone so young, Michelle is wise. She tucks her blonde hair behind her ear before beginning to speak to Hassan, apologizing for the damper she will put on his optimism. "I think you should know that in America, people are not open to new people. Black and White treat each other as enemies.” Like usual, Michelle seems apologetic for the way people are; she wishes people were different. But she is not apologetic for bringing what she sees as realism into the discussion. She seems to be saying: 'Let me tell you about how Lewiston is.'

"I was born here in Lewiston, Maine... lived in the same house all my life, never moved." Lewiston is "kind of like the Bronx of Maine. Everybody thinks about Lewiston, they think about like, oh, crummy town, no one wants to talk to them, they're like punks, thieves, scrubs, and all that.” Michelle goes on. Lewiston is not only perceived like the Bronx from the outside, but — she thinks — it feels like it on the inside too. Michelle throws her hands up in the air. Her young face reflects momentary clarity on what usually wrinkles her brow in frustration and confusion. "People isolate themselves...the Whites are unknown to the Somalis and the Somalis are unknown to the Whites and some people are afraid of what they don't know.” Refusing to get caught up in generalities — “my 
teachers," she says, "tell me to use examples” — Michelle tells me about her family. "My Dad...thinks that [having Somali friends] is just wrong.... I will quote him, 'they are all f-ing Negroes who all want one thing, they just want sex....' We get in mad arguments all the time about it.” Michelle’s little hands have curled into tight balls as she speaks. She looks down at them, shocked, as she finishes her sentence. “Grr,” she says. "That's all I can say is 'Grr.'” But she does not stop there. “I don’t think I’ve ever seen [my Dad] talk to a colored person of his own free will. It's pretty disturbing.” Michelle looks not only disturbed, but also puzzled. "It is confusing," she says, "they see [the Somalis] as completely different people.... Hello, $20^{\text {th }}$ century, wake up, this is America!"

Michelle seems on auto-pilot when talking about her father, as if painting herself in contrast is a kind of catharsis. "I walked with [Hassan] to my house and my Dad, oh my God, my Dad started following us, so I just walked him to the library. But my Dad was being a jerk. It's really frustrating and I don’t like it. He came to the movies one day and I was with like all of them [Somalis], my friends, and my brother put me on his shoulder and took me out. That was embarrassing.” I probe gently, “[a]nd do you think that's because you were with Somalis or because you were with boys, or both? “Well, now that you say it,” Michelle laughs, “I think it really has to do with both. But I don’t think they really recognized the fact that they were guys, the color more. Because if I was like with a bunch of White guys, they wouldn't have cared because I was with Nicole too, 
my friend. The fact that they were of color, it was 'no can’t do!' My ex-boyfriend, he doesn't like them whatsoever. And every time I am with them, he calls the cops and causes trouble and threatens them. And that's wrong, friggin' wrong. Like last time, I had to be taken home in a police cruiser because I refused to leave. I hate having to chose between friends like that.” Assertive and confident beyond her years, Michelle refuses to choose.

Hassan is looking for an explanation for what he calls this "negativity.” “They are scared to talk to each other," he says quietly. "Scared is the most biggest thing." Hassan is never scared in school, he says. But outside, he is sometimes.

Hassan: $\quad$ I know where [Michelle's house] is, but I never actually went in there. Parents, scared, me, very scared.... I was just walking with her and I was in the middle, walking, talking. Her Dad is walking around the house...he followed us, he didn't really follow us, but he was walking around, you know what I mean. You know how scared I got?... How would she like it if she was in Hillview [where I live] and a person was following her?

Michelle: $\quad$ Oh my God, that's too funny. Totally, my Dad hates colored people or whatever. Hates 'em. Loves his grandchild to death, but...

Hassan: He what?

Michelle: $\quad$ Loves his grandchild. She’s Black, or part Black.

Hassan: $\quad$ Well, that's not the part he loves, I guess.

Hassan and Michelle talk to each other about race and inter-racial friendships easily. They give me clues that these are common topics for them — 'Remember when we talked about...' and 'Michelle told me she thinks..., but I think...' It is 
not only my questions that prompt them to think on and discuss these deep and sensitive issues.

Sometimes I wonder if dwelling on the hate and racism they see in their communities and in their families might inspire in Hassan and Michelle self-hate and anger toward each other. But the two students in front of me radiate a hope that seems able to overcome the kind of hate and anger I fear. I see them adamantly expressing that race is not a sub-text, as it is in so many interactions in Lewiston. The set of their chins, the tone of their voices, the attitude in their teenage bodies shouts: "I will be different." When they talk about the values that guide their lives, the things that they are one hundred percent sure of deep inside, they both — independently — tell me: "I’ll never be a racist,” “I won’t ever be a racist.” In the charged environment of Lewiston, in order not to be racist, it seems likely that they need to talk about race and racism, explicitly. While through this talk they define themselves in opposition to the larger community, they use each other as touchstones. They are perhaps each other's best teachers.

\section{Coming to the Collective: Identification}

“What does it feel like to put yourself in Michelle’s shoes?” I ask Hassan as the three of us sit around a table. Michelle smiles and, kicking her feet up on the chair beside her, says: "Probably painful since his feet are much bigger than mine.” We laugh together. 
"No, she doesn’t mean that way,” Hassan takes back control of his question. "But my feet are bigger than hers.” He laughs and then continues seriously. "For me to put myself in Michelle’s position would be ... very hard because I [can't] be doing what she be doing.... But if I was a White woman in this school, how would I feel? I could run around! ... Like actually just feel not looked upon. Like I feel that...”

Michelle puts her feet down and looks Hassan square in the eyes. She cuts him off. "But it's different because I'm White and I talk with you guys and so the people who don't talk to you guys think I'm a ho and I'm a slut and all that."

"Really?”

"Yeah!"

"I didn’t know that. Now I know. I'm sorry.” Hassan laughs in a selfconscious but break-the-tension kind of way. "I would feel more comfortable," he continues to put himself in Michelle’s shoes, “you know what I mean, I guess, I think. But she just told me that I don't think I'd feel the same anymore, so I'd just feel like the same way I felt. So there wouldn't be no change.” He stops to think. "If I was the Principal, there would be some changes, definitely some changes."

“No rules!” Michelle exclaims.

“No, that's not it. Just 'cause I'm White, you know what I mean. Like, I can actually go out, you know, in public as an adult and not feel the same way as if my uncle went in public he'd be looked [at] differently. But if I went there [as 
the White Principal], it'd be like normal, I guess. It's like me being in Boston with all Black people around me. It’s like nothing really matters. Nobody cares...”

“What about you, Michelle, if you were going to put yourself in Hassan’s shoes?” I ask.

“I don’t think she can handle it,” Hassan says mockingly.

Michelle remains serious. "I think I'd feel kind of like an outcast, sort of. But, I don’t know. He has like a lot of friends...”

“A lot!” Hassan looks the most annoyed I have seen him.

“...I guess they make him feel welcomed or whatever. But there is some people that, like, say ‘Oh My God, he’s Black, he’s Somalian [sic] and he’s evil, like don't come near me, and they're mooching off our taxes.'”

“Man, they took \$18 out of my [paycheck in] taxes. I swear to God, I got my paycheck right now...," Hassan reaches to pull it out of his pocket, determined to combat the hurtful stereotype that has resulted in such articles as 'The Great Somali Welfare Hunt' in The American Conservative (McGrath, 2002). “That’s messed up.”

“Welcome to America...," Michelle says with a wag of her head and a sucking of teeth.

This time Hassan remains serious. "If you ever were [in my shoes], just look down....'cause you're going to see things you're gonna hate from other people, you know what I mean.... I just keep walking.” 
Michelle, again, looks Hassan straight in the eye. "It makes you the better person doing that," she says in complete honesty. It is as if she sees right into people, pulls out their strengths with both her hands, and offers them up as gifts of words.

"I didn’t know that. But thanks,” Hassan shrugs in his humble way. “That's not what I do that for, but thank you...." He waits for Michelle to respond. When she doesn't, he mimics "You're welcome, Hassan.” Oops, says Michelle’s expression and she hurriedly replies: "You're welcome.” We all laugh.

In some ways Hassan and Michelle just want to be teenagers, to make money, to go to movies (but "not Bridget Jones, that movie stinks”), to be cool. When I meet them after school for our last interview, they are lying on the floor beside the classroom that is ours for the evening. The hall is empty except for these two adolescent bodies. Michelle lies with her head on her backpack, propped up against one of the endless row of bright yellow lockers. Hassan is similarly slouched on the floor, his crooked arm serves as his pillow and his gangly legs ride half way up the locker beside Michelle. They are talking in low voices, sharing confidences with each other in a way that adults wish they still could, as if there were nothing else going on in the world, as if they were alive only to listen to each other. 
I can look at Hassan and Michelle at this moment and see stereotypical teenagers: slouching and lazy, self-absorbed and spoiled. But Hassan and Michelle have let me inside, and I now know that they stand in stark contrast to this image of teenagers. They are polite and generous, to me but most of all to each other. They care about themselves, but also about others, about their community, and about a more just world that they imagine creating for their children. When asked about their hopes for the future, they do not talk of money and fame; they describe in detail the values that they want to teach these children. And they are just as comfortable telling me about the thoughts of their friend as about their own. "Michelle wants to tell her kids not to drink, not to do drugs, and if they are having sex to tell her,” Hassan looks at Michelle for confirmation, and she nods her head. "Not me,” he continues, “I’d rather not have [my kids] do it at all. I'd rather not have them know what a condom is. Seriously... I'm just going to tell them that they can’t date anyone until they're married.”

“Yup, we're different,” Michelle shrugs and gives Hassan a playful punch on the arm. But it is OK, Hassan waxes, “because I'm a double-thinker.... I put myself in other people’s shoes.” Hassan's philosophy is that as long as he can be different with people and in their shoes, rather than against them as so often happens in Lewiston, "good things happen, at least so far." "It's hard for me [to double-think],” Michelle says, “I guess because I'm stubborn.” But she thanks her 
stubbornness, too, for getting her out from under her father’s prejudice. Now "I get along with a lot of people...I got to actually open up and know them.” Hassan consistently talks about how “people can change.” In a way that is wise beyond his years, he marvels at the human capacity to learn. He admires Michelle’s ability to learn how to “double-think," to "get better at it.” And he shows how he himself found the ability to think differently when he saw a video about Matthew Shepherd’s murder; “I don’t like gay guys either, but I cried because he got beat up.” Michelle cringes at the way Hassan speaks about gays. She shakes her head and sighs, in a way that lets me know they have had this conversation before. "I know you are not used to gays,” Michelle says patiently. "But the way you talk, you know it’s kinda, like, racist.” Hassan changes the subject. As I sit there listening, I know that Hassan and Michelle can still challenge themselves further on their beliefs and stereotypes. But I have learned that they are invested enough in each other that they will continue that challenge, and they will move forward together.

\section{Discussion}

The private friendship that Hassan and Michelle built took place against a very public struggle for relationships between Somalis and Whites in Lewiston. "I think what you are seeing with Michelle and Hassan is unique,” ELL teacher Laurie tells me. “I don’t even see color, I really don’t,” she says. “I don’t even 
think about it.” But she contrasted her 'colorblind' perspective to what she saw from others: acceptance of new people is rare in Lewiston, she says from experience. “I’m not from here, I’m from ‘away,"” she says. “I still do [feel like an outsider].... It's this northern New England thing, or this Maine thing. They pride themselves on keeping outsiders outside, you know. You are from 'away'.... They like saying that to you; it's almost an insult.... I've lived here since 1981 and it's still that way.” And Laurie does not have the barriers of race or religion.

The relationship that Hassan and Michelle developed over the past three years is unique. Michelle is clear that most of the White students at Lewiston High School, kids “I was little with,” do not have Somali friends. But Hassan and Michelle see their friendship as tied into a larger web of relationships between Somali and White students. Having friendships across lines of race, religion, and gender is hard to do, especially if it can mean peer rejection in an insular community. It is clear that Hassan and Michelle do not care much what others think. But, in moments when it is too hard for a teenager to be different, they rely on a small group of Somalis and Whites at Lewiston High School who have figured out a way to be different, together. Hassan and Michelle are this group’s core.

“What do you think that people in Lewiston can learn from you?” I ask Hassan and Michelle together, in a calm and relaxed moment in our last 
conversation. We have just finished looking at the murals painted on the walls of the classroom, seeing in them fantastical shapes as we would on a summer day, splayed out on the grass, looking up at puffy white clouds. Michelle snaps out of her daydream, a quizzical look on her face. "I hate to say this, but they are pretty much stuck in their own ways. I think eventually that we'll be all working together in one place and White people will eventually have to open up and to connect with Somalians [sic] to get the job done, or you're going to get fired. But they're not going to really do it on their own free will. I think they have to be forced. They need a kick in the butt.... It's hard for them to grasp the concepts.” Hassan looks deflated. 'What about all the learning we have been talking about?' his expression seemed to ask. This wisdom comes out in teenage language: "Who was the first person [Somali] in this school to go out with a White person?” He holds his hands high in the air, putting himself out there for all to see. "Me."

Hassan walks the walk. He embodies connection between people. Sliding down the hall from his locker — "the only one with the blue lock", he grins — he greets everyone. The Somali boy half-way in the door to his next class, "I got your back,” he says with a wave. The White guy stuck up against his locker kissing his girlfriend. "What's up," his head bobs in the direction of this friend. “Some people are really open, like Hassan,” Michelle tells me. “He don’t care what anyone thinks or what anyone says. He’s, like, 'hey what's up,' 'can I sit next to you and talk to you.’” Michelle pauses, reflective, and in her habitual 
selfless way finds strength in her friend: "We need a lot more people like him.” We need a lot more people like Michelle, too.

\section{Implications for Theory and School-Based Practice}

If left to chance, it is likely that the kind of bridging relationship that Hassan and Michelle created will remain rare. However, through their own relationship-building, Hassan and Michelle illuminate processes by which they used the opportunity for contact within their school for cooperative action and, ultimately, for collective identification. A re-examination of the theoretical propositions outlined at the outset of this article, in light of Hassan and Michelle's example, provides new insights into how bridging relationships are built. It also suggests ways in which schools, which are uniquely placed to create opportunities for the development of such relationships but which are at present not tooled to do so, might seek to develop bridging relationships intentionally and purposefully.

The relationship between Hassan and Michelle highlights the relevance of more than fifty years of research on interracial contact (e.g., Allport, 1979 [1954]; Brewer \& Miller, 1988; Pettigrew \& Tropp, 2006) to contact between immigrant and long-time resident youth. The catalyst for Hassan and Michelle’s relationship was indeed the contact they had in their school. In contrast, Lewiston High School was not a place of contact for all immigrant youth. Most Somali youth, as Hassan described, were segregated into English Language Learner (ELL) classes, where 
they did not have the opportunity to interact with non-Somalis through classroom activities that promoted personal interaction and cooperation. Similarly, Michelle and other White, English-speaking Lewiston High School students only had contact with the few Somali students who, like Hassan, were in "mainstream" classes. Hassan’s and Michelle’s experiences support research that suggests a more inclusive approach to English-language instruction as a strategy to promoting immigrant integration in schools (Brisk, 1994; Olsen, 1997; Rolstad, Mahoney, \& Glass, 2005; Slavin, 1985). Indeed, when they only shared the space of a school, Hassan was “[j] ust another one of the Hassans” to Michelle. Once together in the same classroom, however, Hassan and Michelle got to know each other and built a bridging relationship based on friendship. Yet other students in their classroom did not have the same experience. Even when Somalis were in “mainsteam” classrooms, Hassan and Michelle described the "flocking together" phenomenon, whereby Somali youth chose to sit together (or perhaps it was White youth who chose to sit together). How then did Hassan and Michelle build their relationship?

In examining the processes by which Hassan and Michelle built their relationship, we can identify mechanisms for building bridging relationships that contribute both to theory and to school-based practice. Like in other empirical work (e.g., Johnson \& Johnson, 1995; Schofield, 1995; Slavin, 1995), equal status contact conditions proved particularly critical for Hassan and Michelle. In the city 
of Lewiston, Hassan did not feel comfortable. He described being looked at and treated as if he did not know much, surrounded by a culture and discourses embedded in racism. As Critical Race Theory observes, "racism is normal, not aberrant, in American society” (Delgado, 1995, p. xiv). Hassan and Michelle experienced racism in their school as well; in this context, Hassan also felt "looked upon” and Michelle described being seen as a "ho" and a "slut” because she talked to Somalis.

Despite these settings that do not fit the equal status conditions of contact theory, Hassan and Michelle did feel comfortable in some situations. Through collaborative assignments and class discussions, teacher Anita Curran invited students to get to know each other better and to begin to care about each other. Through this cooperative action, she encouraged dialogue and relationships among herself and students and among students themselves. Similarly, Hassan’s experience with the Civil Rights Team allowed him and a small, diverse group of other students to work together to “make a difference.” As evidenced by Hassan’s reaction to his Principal's thank you note, through the work, he became invested in what the group was doing as a team. The effects of this kind of cooperative pedagogy in developing empathy and mutual understanding among students are well-documented (e.g., Aronson \& Patnoe, 1997; Slavin \& Cooper, 2002; Stephan \& Finlay, 2002).

While these cooperative experiences allowed Hassan and Michelle 
personal interaction through which they developed an interest in knowing each other better, they were but the jumping off point for a deeper relationship created outside of classroom structures. It is in this way that Hassan and Michelle had different experiences than their classmates. Hassan and Michelle talked openly about their differences, most particularly about race, in ways that most Americans do not (e.g., Pollock, 2004; Tatum, 1992; West, 1993). Like the Lewiston High School ELL teacher Laurie Thompson who refused to see race, other studies have found that even when asked directly about race, educators often dismiss race as irrelevant (Powell, 1997; Schofield, 1999). Smith-Maddox and Solórzano also found that in their teacher education classes, students did not talk about race and racism even when the situation was clearly about race (2002, p. 77). In talking directly about race, Hassan and Michelle modeled for other youth and for educators a new, and difficult, endeavor. The outcome is illuminating in its effects on their bridging relationship: Through talk about race, Hassan and Michelle helped each other to understand the world from each other's point of view, creating within their relationship recognition of their individual differences and strengths. One could see their interactions as providing counter-stories to each other, just as Critical Race Theorists use counter-stories to “challenge the perceived wisdom of those at society’s center” (Solorzano \& Yosso, 2002, p. 36). Hassan labeled as “double-think” his ability to receive a counter-story, or to put himself in someone else’s shoes. "Double-thinking” is a skill that teachers 
often cultivate purposefully among students through, for example, literature and history (e.g., Cullinan, Dove, Estice, \& Lanka, 2008; Kohlmeier, 2006; Louie, 2005; Yilmaz, 2007); Hassan and Michelle demonstrated the potential impact of explicitly using this strategy as a way to foster understanding between students. The skill of “double-thinking," which Hassan exhibited, and which Michelle stated she was cultivating, was central to their mutual understanding of each other as individuals as well as of the experiences of the spaces they each inhabited, particularly their school and the Lewiston community. This kind of mutually interested relationship, as outlined at the beginning of this article, is the foundation of bridging social capital; but again, how did they create it?

Observing Hassan and Michelle, it was clear that they used skills of both storytelling and listening to “double-think” effectively. Each of them explained how they felt in a given situation as well as the processes by which they made sense of the tensions amid which they live; in this way, they practiced what Critical Race theorists do, adopting the "responsibility to demonstrate the complexities of people's lives and the contexts influencing the choices they make” (Chapman, 2005, p. 48). Further, Hassan and Michelle listened to each other in ways that were “deliberate, conscious, and open” (Delgado Bernal, 2002, p. 116), as do both Critical Race theorists and portraitists. Listening with this open stance, they not only heard stories that defied stereotypes, they heard stories of prejudice, of fitting in, of fighting for beliefs, and of dreams for the future that 
reminded them of themselves. As Turner et al. suggest, they began to see themselves “as a collective or joint unit, to feel a sense of 'we-ness"” (1987, p. 34).

This transformation of identity may be the most critical, and yet to date the least theorized, process in building bridging relationships. Hassan and Michelle demonstrated that mutual investment was central to the transformation of identity, as social identity theorists have long argued (e.g., Gaertner \& Dovidio, 2000; Turner, et al., 1987). They showed, through their words and their body language, that they would take the time to explain their thinking and to expose their tensions because they cared that the other person understood. They learned from each other about the role of race in the institutions - school, family, municipality - that they inhabited. Hassan taught Michelle about his personal experiences as a Somali youth in Lewiston and Michelle taught Hassan about the White racism she lived amidst and the entrenched inequity she saw as part of the country that was now his home, too. Hassan and Michelle’s examples support Kramer’s fusion of social identity and social capital theories, positing that personal, bridging relationships are related to collective identification (Kramer, 2006); yet while Kramer argues that collective identification leads to investment in personal relationships, Hassan and Michelle’s examples suggest that experiences in personal relationships created through institutions such as schools might lead, over time, to collective identification. Further study of this process is needed. 
Social capital theory suggests that in order for bridging relationships to be most successful, they require individuals to transcend their own identities (Putnam, 2000, p. 411). While Hassan and Michelle may be transformed through their relationship, this new collective identity did not exist apart from, or transcend, the social, political, and racial identities that were their own. Hassan and Michelle did not agree on many issues including sexual orientation, drugs, and dating. In this way, collective identification for Hassan and Michelle was not about becoming the same; it was about the mutual respect they had for each other and for their differences. Nevertheless, analysis of Hassan and Michelle’s relationship leaves questions about how similar immigrant and long-time resident youth need to be at the outset in order to engage themselves, or to accept teachers' encouragement, in the process of forming a bridging relationship. In Hall's study of Punjabi Sikh youth in Britain, she notes that immigrant students who, like Hassan, were outgoing and open were more able to connect to British peers (Hall, 2002). In their relationships, racialized immigrant youth were asked to carry the burden of transforming to a greater extent than long-time residents. The same is certainly true of Hassan, while not underestimating Michelle’s transformation away from her family.

Hassan and Michelle capitalized on the common space of their new immigrant destination school to transform casual personal interactions into a bridging relationship based on collective identification. Through dialogue, 
particularly about race, they challenged each other and themselves, and each came to understand the other in new ways; they also became invested in each other and dependent on each other to grow and to understand themselves and their places in a changing town. This portrait contributes to theoretical understandings of the processes of personal interaction, cooperative action, and collective identification that contribute to the building of bridging relationships between immigrant and long-time resident youth. It also reveals the value of a focus on race when thinking about, researching, or cultivating these bridging relationships. It is hoped that Hassan and Michelle’s examples might inspire youth and adults in schools across the country to use strategies such as direct dialogue about race and “double-thinking” to foster bridging relationships among other immigrants and long-time residents. 


\section{Notes}

1. I would like to thank Hassan and Michelle for being such thoughtful and inspiring teachers and Sara Lawrence-Lightfoot for her generous and wise mentorship. Thank you also to Soo Hong, Priya G. Nalkur, Carolyn Heang Rubin, Abigal Williamson, and Lyn Corno and three anonymous reviewers from TCR for insightful comments on earlier drafts. The Dean's Office of the Harvard Graduate School of Education supported this work.

2. Names of students and teachers have been changed.

\section{References}

Alder, P. S., \& Kwon, S.-W. (2002). Social Capital: Prospects for a New Concept. The Academy of Management Review, 27(1), 17-40.

Allport, G. (1979 [1954]). The nature of prejudice. Reading, MA: AddisonWesley Publishing Company.

Aronson, E., \& Patnoe, S. (1997). The jigsaw classroom : building cooperation in the classroom (2nd ed.). New York: Longman.

Backenroth, O. A. (2004). Art and Rashi : A Portrait of a Bible Teacher. Religious Education, 99(2), 151-166.

Bourdieu, P. (1986). The Forms of Capital. In J. G. Richardson (Ed.), Handbook for the Theory and Research for the Sociology of Education (pp. 241-258). New York: Greenwood Press. 
Bourdieu, P. (1998). Practical reason : on the theory of action. Cambridge: Polity Press.

Brehm, S. S., \& Kassin, S. M. (1996). Social psychology (3rd ed.). Boston: Houghton Mifflin.

Brewer, M. B., \& Miller, N. (1984). Beyond the contact hypothesis: Theoretical perspectives on desegregation. In N. Miller \& M. B. Brewer (Eds.), Groups in contact: The psychology of desegregation (pp. 281-302). Orlando, FL: Academic Press.

Brewer, M. B., \& Miller, N. (1988). Contact and cooperation, when do they work? In P. Katz \& D. Taylor (Eds.), Eliminating Racism. Profiles in Controversy (pp. 315冈-326). New York: Plenum Press.

Briggs, X. d. S. (2003). Bridging Networks, Social Capital, and Racial Segregation in America. Cambridge: Harvard University.

Brisk, M. E. (1994). Portraits of success: Resources supporting bilingual learners. Boston, MA: Massachusetts Association for Bilingual Education.

Brown, R. (1995). Prejudice: Its Social Psychology. Cambridge: Blackwell.

Bump, M. N., Lowell, B. L., \& Pettersen, S. (2005). The Growth and Population Characteristics of Immigrants and Minorities in America's New Settlement States. In E. M. Gozdziak \& S. F. Martin (Eds.), Beyond the Gateway: Immigrants in a Changing America. New York: Lexington Books. 
Chapman, T. K. (2005). Expressions of "Voice" in Portraiture. [Journal article; methdology]. Qualitative Inquiry, 11(1), 27-51.

Chapman, T. K. (2007). Interrogating Classroom Relationships and Events: Using Portraiture and Critical Race Theory in Education Research. Educational Researcher, 36(3), 156-162.

Coenders, M., \& Scheepers, P. (2008). Changes in Resistance to the Social Integration of Foreigners in Germany 1980-2000: Individual and Contextual Determinants. Journal of Ethnic \& Migration Studies, 34(1), 126.

Coleman, J. S. (1988). Social capital in the creation of human capital. American Journal of Sociology, 94(Supplement), S95-S120.

Cullinan, B., Dove, T., Estice, R., \& Lanka, J. (2008). Becoming Conscious of Different Perspectives. Social Studies and the Young Learner, 20(4).

Delgado Bernal, D. (2002). Critical Race Theory, Latcrit Theory, and critical raced-gendered epistemologies: Recognizing students of color as holders and creators of knowledge. Qualitative Inquiry, 8(1), 105-126.

Delgado, R. (Ed.). (1995). Critical Race Theory: The cutting edge. Philadelphia: Temple University Press.

Dewey, J. (1958 [1934]). Art as experience. New York: Capricorn. 
Dixson, A. D., \& Rousseau, C. K. (2005). And we are still not saved: critical race theory in education ten years later. Race, Ethnicity \& Education, 8(1), 727.

Duncan, G. A. (2002). Beyond Love: A Critical Race Ethnography of the Schooling of Adolescent Black Males. Equity \& Excellence in Education, 35(2), 131.

Ellison, C. G., \& Powers, D. A. (1994). The contact hypothesis and racial attitudes among Black Americans. Social Science Quarterly, 75(2), 385400.

English, F. W. (2000). A Critical Appraisal of Sara Lawrence-Lightfoot's Portraiture as a Method of Educational Research. Educational Researcher, 21-26.

Fishbein, H. D. (1996). Peer prejudice and discrimination: Evolutionary, cultural, and developmental dynamics. Boulder, CO: Westview Press.

Forbes, H. D. (1997). Ethnic Conflict: Commerce, Culture, and the Contact Hypothesis. New Haven: Yale University Press.

Foster, M. (1998). Black teachers on teaching. New York: The New Press.

Fullan, M. G., \& Miles, M. B. (1992). Getting reform right: what works and what doesn't. Phi Delta Kappan, 73, 744-752.

Gaertner, S. L., \& Dovidio, J. F. (2000). Reducing intergroup bias : the common ingroup identity model. Philadelphia, PA: Psychology Press. 
Geertz, C. (1973). The interpretation of cultures. New York: Basic Books.

Gittell, R., \& Vidal, A. (1998). Community Organizing: Social Capital as a Development Strategy. Thousand Oaks, California: Sage Publications.

Gozdziak, E. M. (2005). New Immigrant Communities and Integration. In E. M. Gozdziak \& S. F. Martin (Eds.), Beyond the Gateway: Immigrants in a Changing America. New York: Lexington Books.

Gozdziak, E. M., \& Martin, S. F. (2005). Beyond the gateway : immigrants in a changing America. Lanham: Lexington Books.

Hackmann, D. G. (2002). Using portraiture in educational leadership research. International Journal of Leadership in Education, 5(1), 51-60.

Hall, K. (2002). Lives in translation : Sikh youth as British citizens. Philadelphia: University of Pennsylvania Press.

Halpern, D. (2005). Social capital. Cambridge, UK ; Malden, MA: Polity.

Harding, H. A. (2005). "City Girl": A Portrait of a Successful White Urban Teacher. Qualitative Inquiry, 11(1), 52-80.

Hood III, M. V., \& Morris, I. L. (1997). Amigo o Enemigo? Context, attitudes, and Anglo public opinion toward immigration. Social Science Quarterly, 78(2), 309-323.

Iseke-Barnes, J. M. (2000). Ethnomathematics and language in decolonizing mathematics. Race, Gender \& Class in Education, 7(3), 133-149. 
Johnson, D. W., \& Johnson, R. T. (1995). Social interdependence: Cooperative learning in education. In B. B. Bunker \& J. Z. Rubin (Eds.), Conflict, cooperation, and justice: Essays inspired by the work of Morton Deutsch (pp. 205-251). San Francisco: Jossey-Bass.

Kawachi, I., \& Berkman, L. F. (2000). Social cohesion, social capital and health. In L. F. Berkman \& I. Kawachi (Eds.), Social Epidemiology. Oxford: Oxford University Press.

Kohlmeier, J. (2006). "Couldn't She Just Leave?": The Relationship between Consistently Using Class Discussions and the Development of Historical Empathy in a 9th Grade World History Course. Theory and Research in Social Education, 34(1), 34-57.

Kramer, R. M. (2006). Socal Identity and Social Capital: The Collective Self at Work. International Public Management Journal, 9(1), 25-45.

Kunz, J. L. (2003). Social Capital: A Key Dimension of Immigrant Integration. Canadian Issues(April), 33-34.

Ladson-Billings, G. (1999). Preparing teachers for diverse student populations: A Critical Race Theory perspective. Review of Research in Education, 24, 211-247.

Ladson-Billings, G., \& Tate IV, W. F. (1995). Toward a critical race theory of education. Teachers College Record, 97(1), 47. 
Lawrence-Lightfoot, S. (2005). Reflections on Portraiture: A Dialogue Between Art and Science. Qualitative Inquiry, 11(1), 3-15.

Lawrence-Lightfoot, S., \& Davis, J. H. (1997). The Art and Science of Portraiture. San Francisco: Jossey-Bass.

Louie, B. (2005). Development of Empathetic Responses With Multicultural Literature. Journal of Adolescent and Adult Literacy, 48(7), 566-578.

Lynn, M., \& Parker, L. (2006). Critical Race Studies in Education: Examining a Decade of Research on U.S. Schools. Urban Review, 38(4), 257-290. Marinell, W. H. (2008). Capturing Authenticity, Transforming Perception: One Teacher's Efforts to Improve Her Students’ Performance by Challenging Their Impressions of Self and Community. Harvard Educational Review, 78(3).

Matsuda, M. J., Lawrence, C., Delgado, R., \& Crenshaw, K. (1993). Words that wound: critical race theory, assaultive speech, and the First Amendment. Boulder, Colo.: Westview Press.

McGrath, R. D. (2002, November 18, 2002). Coming to America: The Great Somali Welfare Hunt. The American Conservative.

McPherson, J. M., Smith-Lovin, L., \& Cook, J. (2001). Birds of a Feather: Homophiliy in Social Networks. Annual Review of Sociology, 27, 415444. 
Migration Policy Institute (2004). Building the New American Community: Newcomer Integration and Inclusion Experiences in Non-Traditional Gateway Cities. Washington, DC: Migration Policy Institute.

Molina, L. E., \& Wittig, M. A. (2006). Relative Importance of Contact Conditions in Explaining Prejudice Reduction in a Classroom Context: Separate and Equal? Journal of Social Issues, 62(3), 489-509.

Murakami-Ramalho, E., Piert, J., \& Militello, M. (2008). The Wanderer, the Chameleon, and the Warrior: Experiences of Doctoral Students of Color Developing a Research Identity in Educational Administration. Qualitative Inquiry, 14(5), 806-834.

National Research Council (2002). Scientific Research in Education. Washington, DC: National Academy Press.

Newton, R. M. (2005). Learning to Teach in the Shadow of 9/11: A Portrait of Two Arab American Preservice Teachers. Qualitative Inquiry, 11(1).

Olsen, L. (1997). Made in America : immigrant students in our public schools. New York: New Press : Distributed by W.W. Norton \& Co.

Orfield, G., \& Lee, C. (2006). Racial Transformation and the Changing Nature of Segregation. Cambridge, MA: The Civil Rights Project at Harvard University.

Perham-Whittier (2007). 2007 All-American City Award Application. Lewiston, ME: City of Lewiston. 
Pettigrew, T. F., \& Tropp, L. R. (2006). A meta-analytic test of intergroup contact theory. Journal of Personality and Social Psychology, 90, 751-783.

Pollock, M. (2004). Colormute: race talk dilemmas in an American school. Princeton: Princeton University Press.

Powell, L. C. (1997). The Achievement (K)not: Whiteness and 'Black Underachievement. In M. Fine, L. Weis, L. C. Powell \& L. M. Wong (Eds.), Off White: Readings on Race, Power, and Society. Florence, KY: Routledge.

Putnam, R. D. (2000). Bowling Alone: The Collapse and Renewal of American Community. New York: Simon \& Schuster.

Putnam, R. D. (2007). E Pluribus Unum: Diversity and Community in the Twenty-First Century: The 2006 Johan Skytte Prize Lecture. Scandinavian Political Studies, 30(2).

Raymond, L. (2002, October 1, 2002). Mayor appeals to Somalis to stem immigration. Lewiston Sun Journal,

Rolstad, K., Mahoney, K., \& Glass, G. (2005). The Big Picture: A Meta-Analysis of Program Effectiveness Research on English Language Learners. Educational Policy, 19(4), 572-594.

Saegart, S., Thompson, J. P., \& Warren, M. R. (Eds.). (2001). Social Capital and Poor Communities. New York: Russell Sage Foundation. 
Schofield, J. W. (1995). Promoting positive intergroup relations in school settings. In W. D. Hawley \& A. W. Jackson (Eds.), Toward a common destiny: Improving race and ethnic relations in America (pp. 257-289). San Francisco: Jossey-Bass.

Schofield, J. W. (1999). The Colorblind Perspective in School: Causes and consequences. In J. Banks \& C. A. M. Banks (Eds.), Multicultural Education (4th ed.). Boston: Allyn and Bacon.

Sigelman, L., \& Welch, S. (1993). The contact hypothesis revisited: Black-White interaction and positive social attitudes. Social Forces, 71, 781-795.

Singer, A. (2004). The Rise of New Immigrant Gateways. Washington, D.C.: The Brookings Institute.

Slavin, R. E. (1985). Cooperative learning: Applying contact theory in desegregated schools. Journal of Social Issues, 41(3), 45-62.

Slavin, R. E. (1995). Enhancing intergroup relations in schools: Cooperative learning and other strategies. In W. D. Hawley \& A. W. Jackson (Eds.), Toward a common destiny: Improving race and ethnic relations in America (pp. 291-314). San Francisco: Jossey-Bass.

Slavin, R. E., \& Cooper, R. (2002). Improving Intergroup Relations: Lessons Learned From Cooperative Learning Programs. Journal of Social Issues, 55(4), 647-663. 
Smith-Maddox, R., \& Solorzano, D. G. (2002). Using Critical Race Theory, Paulo Freire's Problem-Posing Method, and Case Study Research to Confront Race and Racism in Education. Qualitative Inquiry, 8(1), 66.

Solorzano, D. G. (1997). Images and words that wound: Critical race theory, racial stereotyping, and teacher education. Teacher Education Quarterly, 24(3), 5-19.

Solorzano, D. G., \& Yosso, T. J. (2002). Critical Race Methodology: CounterStorytelling as an Analytical Framework for Education Research. Qualitative Inquiry, 8(1), 23.

Stanton-Salazar, R. D. (1997). A Social Capital Framework for Understanding the Socialization of Racial Minority Children and Youths. Harvard Educational Review, 67(1), 1-40.

Stein, R. M., Post, S. S., \& Rinden, A. L. (2000). Reconciling context and contact effects on racial attitudes. Political Research Quarterly, 53, 285-303.

Stephan, W. G., \& Finlay, K. (2002). The Role of Empathy in Improving Intergroup Relations. Journal of Social Issues, 55(4), 729-743.

Tate IV, W. F. (1997). Critical Race Theory and Education: History, Theory, and Implications. Review of Research in Education, 22, 195-247.

Tatum, B. D. (1992). Talking about Race, Learning about Racism: The Application of Racial Identity Development Theory in the Classroom. Harvard Educational Review, 62, 1-24. 
Tatum, B. D. (2003). "Why are all the Black kids sitting together in the cafeteria?" : and other conversations about race. New York: Basic Books.

Tropp, L. R., \& Pettigrew, T. F. (2005). Relationships between intergroup contact and prejudice among minority and majority status groups. Psychological Science, 16(12), 951-957.

Turner, J. C., Hogg, M. A., Oakes, P. J., Reicher, S. D., \& Wetherell, M. S. (1987). Rediscovering the social group: A self-categorization theory. Oxford: Basil Blackwell.

Valencia, R. R. (1997). The evolution of deficit thinking: educational thought and practice. London ; Washington, D.C.: Falmer Press.

Valenzuela, R. R., and Mary S. Black (2002). Mexican Americans don't value education!' On the basis of the myth, mythmaking and debunking. Journal of Latinos and Education, 1(2), 81-103.

Weisinger, J. Y., \& Salipante, P. F. (2005). A Grounded Theory for Building Ethnically Bridging Social Capital in Voluntary Organizations. Nonprofit \& Voluntary Sector Quarterly, 34(1), 29-55.

Welty, E. (2003 [1983]). One Writer's Beginning. Cambridge: Harvard University Press.

West, C. (1993). Race matters. Boston: Beacon Press. 
Wright, T. (2007). On Jorge Becoming A Boy: A Counselor’s Perspective.

Harvard Educational Review, 77(2), 164-186.

Yilmaz, K. (2007). Historical Empathy and Its Implications for Classroom

Practices in Schools. History Teacher, 40(3), 331-338. 